\title{
Analyzing e-service quality in service-based website by E-SERVQUAL
}

\author{
Babak Nemati $^{\mathrm{a}^{*}}$, Hossein Gazor ${ }^{\mathrm{b}}$, Seyed Norollah MirAshrafi ${ }^{\mathrm{c}}$ and Kianoush Nazari Ameleh
}

${ }^{a}$ Department Acoounting \& Management of Payam Noor University of Damavand, Tehran, Iran

${ }^{b}$ Department of Accounting \& Management of Allameh Tabatabai University, Tehran, Iran

${ }^{c}$ Department of Political Science Islamic Azad University of Roudehen, Tehran, Iran

\section{A R T I C L E I N F O}

\section{Article history:}

Received October 10, 2011

Received in Revised form

November, 14, 2011

Accepted 25 November 2011

Available online

3 December 2011

\section{Keywords:}

Leadership style

Organizational effectiveness

Management

Supportive leadership

Democratic Management

\section{A B S T R A C T}

Over the past two decades, two-way communication via web-based exchanges has been a popular method for different activities such as electronic transaction, publication, broadcasting, and other service applications. However, it is always necessary to measure the performance quality of web services using different technique such as e-SERVQUAL model. The proposed study of this paper uses this technique for measuring the quality of Iranian university e-services. The proposed study distributes a standard questionnaire among students who use this service through internet. The results indicate that only efficiency and online service quality in the eservice system are desirable. Managerial implications are represented.

(c) 2012 Growing Science Ltd. All rights reserved.

\section{Introduction}

The internet revolution has changed the way people live and work since many time-consuming and frustrating activities are now performed using the internet facilities. A good quality internet service reduces the cost of services and absorbs more customers. However, a bad quality internet service easily damages the image of a business unit, bringing hard time to management and shareholders. This means that we must review the quality of an internet services using standard techniques. During the past two decades, there have been outstanding attempts on providing best practices for quality measurement (for example, Asher, 1988; Dotchin \& Oakland, 1994, Mels et al., 1997, Xie et al., 1998, Wisniewski, 2001, Candido \& Morris, 2001, etc.).

Service quality (SERQUAL) is a modern technique for measuring quality in different enterprises and organizations and serves the development of a truly customer-focused management and culture (Gazor et al, 2012). Web-based service quality, on the other hand, is a method for measuring the 
quality of services provided based on the web technology such as online communication, purchase and delivery of products/services (Cronin \& Taylor, 1992). There is no virtual value in a product or service until it is delivered to satisfied customer. Customer service is determined by the interaction of all those factors affecting the process of making products/services available to the customer (Christopher, 1998). Multiple-attributes models are widely implemented to measure service quality. Understanding customers' expectation is the necessary step in defining and delivering the high-quality service (Zeithaml et al., 1990; 1996). Expectations play important role to determine the consumer's service quality evaluation and satisfaction (O’Connor et al, 2000). Therefore, many organizations extremely consider service quality to obtain their customers' satisfaction and loyalty (Gazor et al, 2012). Business managers must always listen very carefully to what their customers say as a good feedback to improve the quality of the services. SERVQUAL method proposed by Parasuraman et al. (1988) is one of the best evaluation techniques for assessing the expectations and perceptions. SERVQUAL method has five dimensions to measure service quality, including the tangibles, reliability, responsiveness, assurance and empathy (Zeithaml et al., 1990). Customers monitor the service quality by determining whether there is any gap between their expectations and perceptions.

\section{Literature review}

\subsection{E-service quality}

The idea of e-service is one of the prominent applications of utilizing the use of Information and Communication Technologies (ICTs) in different areas but it is difficult to provide a comprehensive definition for e-service. Along with the development of the internet and web-based technologies, online customers use necessary information on products and services. Zeithaml et al. (2001) is believed to be the first one who provided a formal definition of website service quality or e-service quality. According to Zeithaml et al. (2001), e-service quality is defined as the extent to which a website facilitates efficient and effective shopping, purchasing, and delivering of products and services. As stated, the meaning of service is comprehensive, which includes both pre- and postwebsite service aspects. There are virtually numbers of criteria that customers use in evaluating websites in general and service quality delivery through websites. Some of them include information availability and content, ease of use, privacy/security, graphic style and fulfillment (Babakus et al., 2003; Chang, 2007; Chiu et al., 2005; Zeithaml et al., 2002). E-service quality can be also described as as the consumer's judgment about an entity's (service's) overall excellence or superiority (Zeithaml, 1988).

\subsection{E-SERVQUAL}

Zeithaml et al. (2001, 2002) developed the e-SERVQUAL measure of e-service quality to study how customers judge e-service quality. This new model was drawn up through a three-stage process involving exploratory focus groups and two phases of empirical data collection and analysis. It contains seven dimensions: efficiency, reliability, fulfillment, privacy, responsiveness, compensation and contact. The first four dimensions are classified as the core service scale, and the latter three dimensions are regarded as a recovery scale, since they are only salient when online customers have questions or problems. Contents of each dimension are shown below:

(1) Core service scale in e-SERVQUAL. (a) Efficiency: the capability of customers to access the website, finding their appropriate product and information related to preserving minimum effort. (b) Fulfillment: accuracy of service requirements, availability of the product in storage, and delivering the products on time. (c) Reliability: the technical function of the site, particularly the extent to which it is available and properly functioning. (d) Privacy: assurance that shopping behavior data are not open and that credit card information is secured.

(2) Recovery service scale in e-SERVQUAL. (a) Responsiveness: compares the capability of eretailers to give appropriate data to customers when a problem happens, having mechanisms for 
handling returns, and giving online guarantees. (b) Compensation: consists receiving money back and returning shipping and handling expenditures. (c) Contact. The requirement of customers to speak to a living customer service agent online or on the phone.

\section{Efficiency}

The 'design of the user interface' best provides the quality dimension of tangibility in the SERVQUAL model. It covers overall design (Kaynama \& Black, 2000; Szymanski \& Hise, 2000), ease of navigation (Kaynama \& Black, 2000; Zeithaml et al., 2000), and overall ease of use (Dabholkar 1996), called 'efficiency' in Zeithaml et al. (2000), and aesthetics (Zeithaml et al., 2000).

H1: online service quality efficiency of the university's website is in favorable level.

\section{Reliability}

Reliability is the next SERVQUAL dimension for online services and it is parallel to the case of offline services, where customers expect search engines, payment facilities etc. to function reliably, and the information presented on the website to be dependable. Two aspects of online service reliability can be distinguished (Cox \& Dale, 2001). The reliability perceptions is driven by the correct technical functioning of the site, or the technical aspects of the user interface, while the outcome aspect is defined by the accuracy of service promises, billing and product information (Zeithaml et al., 2000).

H2: online service quality reliability of the university's website is in favorable level.

\section{Responsiveness}

The quality of support customers receive when we face with questions or running into problems, and the speed with which this support is provided, largely determine customer evaluations of post transaction services. Customer support is appreciated during the pre-transaction stage, particularly for online services: the online customer is relatively powerless in enforcing help, having to rely on the willingness of the firm to provide support. The faster a provider responds to requests, the better the service will be evaluated (Van Riel et al, 2004).

H3: online service quality responsiveness of the university's website is in favorable level.

\section{Assurance}

In the classical SERVQUAL model an important quality dimension is assurance, or the degree to which service staff and premises instigate trust in the customer. Online customers generally cannot reach the employees, or the physical facilities of the firm they are dealing with (Reichheld \& Schefter, 2000), so trust needs to be established in other ways. It is the impression of assurance the website makes on the customer, which could lead to trust. The security and privacy dimension used by Zeithaml et al. (2000), which 'involves the degree to which the customer believes the site is safe from intrusion and personal information is protected' (Zeithaml et al., 2000) is part of the assurance dimension. Trust is often claimed to be the most important online service quality dimension (Papadopoulou et al., 2001; Petersen, 2001; Roy et al., 2001; Urban et al., 2000).

H4: online service quality assurance of the university's website is in favorable level.

\section{Security/privacy}

Privacy/security refers to the protection of personal and financial information (Yoo \& Donthu, 2001) and the degree that a site is considered by consumers as being safe from intrusion (Parasuraman et al., 2005). Security has been identified as a vital factor to determine e-service quality for consumers of 
online banking services (White \& Nteli, 2004). Security is the most important factor on intention store visit a site and make purchases (Ranganathan \& Ganapathy, 2002; Yoo \& Donthu, 2001).

H5: online service quality Security/privacy of the university's website is in favorable level.

\subsection{E-service in universities}

There are many studies on e-service in universities, which give confidence that user perceptions of service quality in higher education are similar to those in other domains (Lagrosen et al., 2004). However, the dimensions are different, for instance, library resources and computer facilities are instances of "tangibles" (Lagrosen et al., 2004). E-services in universities consist of many items including financial, administrative, unit selection, registration, payment, score checking, online exam, and so on. Many people apply e-services to obtain several objectives such as developing the university portal, and associated services, evaluating and planning the deployment of an institutional repository. Besides, the services provide the faculty the ability to manage class attendance, view class roasters, and grade students online. It also provides a tool to university employees (Staff \& Faculty) the ability to claim many of their benefits online. Examples of such benefits includes: education allowance, travel reimbursement, Leave, and Air tickets allowance requests. In this paper, we attempt to analyze five dimensions of Zeithamal's e-SERVQUAL in website of Azad universities of Tonekabon and Ramsar.

H6: online service quality of the university's website is in favorable level.

\section{Methodology}

To collect data, authors used standardized questionnaire designed by Zeithamal et al. (2002) namely e-SERVQUAL. It concludes 26 items for 5 factors that mentioned in above section. Respondents were asked to answer questions on a five-point Likert scale, which $1=$ strongly disagree, $2=$ disagree, 3= neutral, 4= agree, and 5= strongly agree. For analyzing data, authors used one-sample t test. A random sample of (400) students out of (10000) at universities in Tonekabon and Ramsar was used in this study. The questionnaire was sent to students e-mail addresses that 304 complete and accurate questionnaires were come back. Survey-sectional method was used for identifying population attributions.

\section{Results}

More than 51 percent of respondents are male. Other demographic data is shown in Table 1.

\section{Table 1}

Demographic data of population

\begin{tabular}{lll}
\hline Characteristic & Number & Percentage (\%) \\
\hline Gender & & 51 \\
Male & 158 & 49 \\
Female & 146 & \\
\hline Age & & 12.5 \\
\hline $15-20$ & 38 & 65 \\
$21-25$ & 197 & 16 \\
$26-30$ & 48 & 6.5 \\
$>31$ & 21 & \\
\hline
\end{tabular}

The results indicate that in terms of efficiency, question 6 receives the highest mean (3.99) and question 1 maintains the minimum number (2.52). In terms of variation, question 24 maintained the maximum mean (4.09). Mean of each question is shown in Table 2. 
Table 2

Variations and mean of indicators

\begin{tabular}{|c|c|c|c|c|}
\hline Variable & Q\# & Indicators & Number & Mean \\
\hline \multirow{6}{*}{ Efficiency } & 1 & Downloading speed of website & 305 & 2.52 \\
\hline & 2 & Main information finding & 305 & 2.54 \\
\hline & 3 & Navigation in website & 305 & 3.13 \\
\hline & 4 & Notifications finding & 305 & 3.54 \\
\hline & 5 & Not amaze user in website & 305 & 3.28 \\
\hline & 6 & Exiting speed from website & 305 & 3.99 \\
\hline \multirow{6}{*}{ Reliability } & 7 & User relying on website performance & 305 & 2.80 \\
\hline & 8 & 24-hours website & 305 & 3.66 \\
\hline & 9 & Not have error in downloading of website & 305 & 3.69 \\
\hline & 10 & Fast downloading links & 305 & 3.60 \\
\hline & 11 & Accuracy of presented information & 305 & 4.06 \\
\hline & 12 & Understandable information & 305 & 3.76 \\
\hline \multirow{6}{*}{ Responsibility } & 13 & Inform user when website in problem & 305 & 2.50 \\
\hline & 14 & Compensate to user when website in problem & 305 & 2.53 \\
\hline & 15 & Online or phone contact with user & 305 & 1.93 \\
\hline & 16 & Having online representations & 305 & 2.49 \\
\hline & 17 & Fast reaction to problems & 305 & 1.94 \\
\hline & 18 & Thirst to help to user in emergent conditions & 305 & 1.90 \\
\hline \multirow{4}{*}{ Assurance } & 19 & Attention to ordered services & 305 & 3.15 \\
\hline & 20 & On time service delivery & 305 & 2.68 \\
\hline & 21 & Fast ratification transmission for entered information & 305 & 3.62 \\
\hline & 22 & Adjustment between presented service and expected service & 305 & 2.10 \\
\hline \multirow{4}{*}{ Security/privacy } & 23 & Enough concern to inter user information & 305 & 3.67 \\
\hline & 24 & $\begin{array}{l}\text { User confidence to entered information (except credit card } \\
\text { information) }\end{array}$ & 305 & 4.09 \\
\hline & 25 & Website confidence to retain credit card information & 305 & 3.62 \\
\hline & 26 & User confidence to not abuse of personal information & 305 & 3.12 \\
\hline
\end{tabular}

To analyze research's findings, we use a sample $t$ test. The result of one-sample $t$ test in Table 3 indicates that sample mean of reliability $(\mathrm{t}=35.50)$, Responsibility $(\mathrm{t}=-32.28)$, assurance $(\mathrm{t}=-5.72)$, and security/privacy ( $\mathrm{t}=22.83$ ) are significantly lower than expected value (3) but sample mean of efficiency $(t=6.71)$ is significantly higher than expected value (3). Generally, the sample mean service quality ( $\mathrm{t}=6.15)$ is significantly higher than expected value (3).

Table 3

One-sample t test for each hypothesis (test value=3)

\begin{tabular}{lllllllll}
\hline Hypothesis & Variation & $\begin{array}{l}\text { Sample } \\
\text { size }\end{array}$ & Mean & $\begin{array}{l}\text { Standard } \\
\text { deviation }\end{array}$ & $\begin{array}{l}\text { Standard error } \\
\text { of mean }\end{array}$ & $\mathrm{t}$ & $\begin{array}{l}\text { Significance } \\
\text { level }\end{array}$ \\
\hline H1 & Efficiency & 300 & 3.16 & 0.42 & 0.02 & 6.71 & 299 & 0.00 \\
H2 & Reliability & 304 & 2.22 & 0.29 & 0.02 & 35.50 & 303 & 0.00 \\
H3 & Responsibility & 301 & 2.22 & 0.42 & 0.02 & -32.28 & 299 & 0.00 \\
H4 & Assurance & 304 & 2.98 & 0.33 & 0.02 & -5.72 & 299 & 0.00 \\
H5 & Security/privacy & 303 & 3.63 & 0.47 & 0.02 & 22.83 & 302 & 0.00 \\
H6 & Online service quality & 296 & 3.07 & 0.21 & 0.01 & 6.15 & 295 & 0.00 \\
\hline
\end{tabular}

The rapid development of information and communication technologies has created tremendous opportunities for many people to access to a wide range of new services over the Internet (Porter, 2001). This research was conducted in response to a call for the continuous challenge about online quality of services. According to Zeithamal et al. (2002), E-SERVQUL model considers five quality measures including efficiency, reliability, Responsibility, assurance, security/privacy, quality of online service (26 items). In this paper, we have attempted to investigate online service quality of 
Tonekabon and Ramsar Universities. Findings indicate that efficiency and total online service quality of university's website were in favorable level. Other variables including reliability, responsiveness, assurance, and security/privacy were not in sufficient level. As online users play an important role in determining e-service quality, firms need to find ways of instilling and motivating positive users' behavior, whereas also managing and discouraging negative users' participation in their e-service settings. From a managerial viewpoint, this paper provides website designers or owners a broad theoretical foundation that designing successful online services should emphasize on website design, reliability and security/privacy and customer service. When customers receive online services, they can easily find their desired services/products and information and even complete the order efficiently. Reliability is associated with accurate presentation of the services and delivery of services on time. Therefore, improving technical functions of the site to possess accurate presentation and credit administration is necessary. Website owners also should pay high concern to privacy or security. Security is a key evaluative criterion in online services. When customers believe it's safe to transmit private information, they will go back to website. Finally, customer service is another key point that requires consideration. Offering diversified contact channels is vital so customers can easily and efficiently communicate with the website. Finally, creating cultural basis for using of ecommerce systems is very important. Switching habits is a difficult work especially in traditional methods that people be accustomed them.

\section{Conclusion}

In this paper, we have presented an empirical investigation on the quality of web services using SERQUAL system. The proposed study of this paper has implemented to measure the quality of a web service, which belongs to a private university in Iran. Findings indicated that efficiency and total online service quality of university's website were in favorable level. Other variables including reliability, responsiveness, assurance, and security/privacy were not in sufficient level. Future research in designing and improving websites will contribute to website managers for increasing customers' satisfaction and loyalty. It will be fruitful to help organizations evaluate their web-based service quality, design improvements and finally embed their websites into future services to achieve customer satisfaction.

\section{References}

Asher, J.M. (1988). The cost of quality in service industries. International Journal of Quality and Reliability Management, 5(5), 38-46.

Babakus, E., Yavas, U., Karatepe, O., \& Avci, T. (2003). The effects of management commitment to service quality on employees' affective and performance outcomes. Journal of the Academy of Marketing Science, 31(3), 272-286.

Candido, C.J.F. \& Morris, D.S. (2001). The implications of service quality gaps for strategy implementation. Total Quality Management, 12, 825-833.

Chang, H.H. (2007). Critical factors and benefits in the implementation of customer relationship management. Total Quality Management \& Business Excellence, 18(5), 483-508.

Chiu, H.C., Hsieh, Y.C., \& Kao, C.Y. (2005). Website quality and customer's behavioral intention: An exploratory study of the role of information asymmetry. Total Quality Management \& Business Excellence, 16(2), 185-198.

Christopher, M. (1998) Logistics and Supply Chain Management: Strategies for Reducing Cost and Improving Service (Pitman).

Cox, J. \& Dale, B. G. (2001). Service quality and ecommerce: an exploratory analysis, Managing Service Quality, 11(2), 121-131.

Cronin, J.J. \& Taylor, S.A. (1992). Measuring service quality: a reexamination and extension, Journal of Marketing, 56(3), 55-68. 
Dabholkar, P. A. (1996). Consumer evaluations of new technology-based self-service options: an investigation of alternative models. International Journal of Research in Marketing, 13 (1), 2951.

Dotchin, J.A. \& Ockland, J.S. (1994). Total quality management in services. International Journal of Quality and Reliability Management, 11(3), 27- 42.

Gazor, H., Nemati, N., Ehsani, A., \& Nazari Ameleh, K. (2012). analyzing effects of service encounter quality on customer satisfaction in banking industry. Management Science Letters, 2, doi: 10.5267/j.msl.2011.11.011.

Kaynama, S. A. \& Black, C. I. (2000). A proposal to assess the service quality of online travel agencies: an exploratory study. Journal of Professional Services Marketing, 21(1), 63-88.

Lagrosen, S., Seyyed-Hashemi, R., \& Leitner, M. (2004). Examination of the dimensions of quality in higher education. Quality Assurance in Education, 12(2), 61-69.

Mels, G., Boshoff, C. \& Nel, D. (1997). The dimensions of service quality: the original European perspective revisited. The Service Industries Journal, 17(1), 173- 189.

O’Connor, S., Trinh, H., \& Shewchuk, R. (2000). Perceptual gaps in understanding patient expectations for health care service quality. Health Care Management Review, 25 (7)-23.

Papadopoulou, P., Andreou, A., Kanellis, P. \& Martakos, D. (2001). Trust and relationship building in electronic commerce. Internet Research: Electronic Networking and Policy 11(4), 322-332.

Parasuraman, A., Zeithaml, V.A., \& Berry, L.L. (1988). SERVQUAL: a multiple item scale for measuring consumer perceptions of service quality. Journal of Retailing, 64(12)-40.

Parasuraman, A., Zeithaml, V.A., \& Malhotra, A. (2005). E-S-Qual: a multiple-item scale for assessing electronic service quality. Journal of Service Research, 7(3), 213-233.

Petersen, A. (2001). Private matters: it seems that trust equals revenue, even online, The Wall Street Journal Europe, Special Section on E-Commerce (February 12), p. viii.

Ranganathan, C., \& Ganapathy, S. (2002). Key dimensions of business-to-consumer web sites. Information and Management 39, 457-465.

Reichheld, F. F. \& Schefter, P. (2000). E-loyalty: your secret weapon on the web. Harvard Business Review, 78(4), 105-113.

Roy, M. C., Dewit, O. \& Aubert, B. A. (2001). The impact of interface usability on trust in web retailers. Internet Research: Electronic Networking Applications and Policy, 11(5), 388-398.

Szymanski, D. M. \& Hise, R. T. (2000). E-satisfaction: an initial examination. Journal of Retailing, 76(3), 309-322.

Urban, G. L., Sultan, F. \& Qualls, W. J. (2000). Placing trust at the center of your Internet strategy. Sloan Management Review, 42(1), 39-48.

Van Riel, Allard C. R., Semeijn, J., \& Pauwels, P. (2004) Online Travel Service Quality: the Role of Pre-Transaction Services. Total Quality Management \& Business Excellence, 15(4), 475-493.

White, H., \& Nteli, F. (2004). Internet banking in the UK: why are there not more customers? Journal of Financial Services Marketing, 9 (1), 49-56.

Wisniewski, M. (2001). Assessing customer satisfaction with local authority services using SERVQUAL. Total Quality Management, 12, 995- 1002.

Xie, M., Goh, T.N. \& Wang, H. (1998). Quality dimensions of internet search engines. Journal of Information Science, 24(5), 87- 94

Yoo, B., \& Donthu, N., (2001), Developing a scale to measure the perceived quality of Internet shopping sites(SITEQUAL).Quarterly Journal of Electronic Commerce, 2(1), 31-47.

Zeithaml, V. A., Parasuraman, A. \& Malhotra, A. (2000). A conceptual framework for understanding e-service quality: Implications for future research and managerial practice. Working Paper, Report Nr. 00-115 (Cambridge, MA: Marketing Science Institute).

Zeithaml, V.A, Berry, L.L., \& Parasuraman, A. (1996). The behavioral consequences of service quality. Journal of Marketing, 60(3), 1-52.

Zeithaml, V.A. (1988). Consumer perceptions of price, quality and value: A means-end model and synthesis of evidence. Journal of Marketing, 52, 2-22. 
Zeithaml, V.A. Parasuraman, A., \& Berry, .L.L. (1990). Developing Quality Service: Balancing Customer Perception and Expectations. The Free Press, New York.

Zeithaml, V.A., Parasuraman, A., \& Malhotra, A. (2001). A conceptual framework for understanding e-service quality: Implication for future research and managerial practice. MSI Working Paper Series, No. 00-115. Cambridge, MA.

Zeithaml, V.A., Parasuraman, A., \& Malhotra, A. (2002). Service quality delivery through web sites: A critical review of extant knowledge. Journal of the Academy of Marketing Science, 30(4), 362375. 